\begin{tabular}{c} 
International Journal of Basic and Applied Sciences, $6(2)(2017) 22-28$ \\
International Journal of Basic and Applied Sciences \\
SPC \\
Website: $\begin{array}{c}\text { ww.sciencepubco.com/index.php/IJBAS } \\
\text { doi: } 10.14419 / i j b a s . v 6 i 2.7483 \\
\text { Research paper }\end{array}$ \\
\hline
\end{tabular}

\title{
Use of plant-derived products to control household and structural arthropod pests
}

\author{
Ruparao T. Gahukar * \\ Arag Biotech Pvt. Ltd., Plot 220, Reshimbag, Nagpur 440 009, India \\ *Corresponding author E-mail: rtgahukar@gmail.com
}

\begin{abstract}
Plant extracts in water or chemical solvents; crude oil, essential oils and other allelochemicals of several plant species were tested at the laboratory as contact poison and/or fumigant. Most of them acted as repellent to insects and mites. Toxicity effect was dose-dependent and varied as per plant species and organism tested. In some instances, plant-derived products causing mortality were less effective than synthetic pesticides. However, considering possible environmental contamination of synthetics and the eventual toxicity to non-target organisms, plant-derived products against household and structural pests have been recommended by researchers. The major pest species with mode of actions of plant products and integrated strategies for effective, practical and ecofriendly pest control are discussed throughout this review.
\end{abstract}

Keywords: Allelochemicals; Insects; Mites; Plant Extracts; Mode of Action; Household and Structural Pests.

\section{Introduction}

Household insect pests are important in dwellings, particularly in urban areas [1]. Currently, these insects are controlled mostly by sprays and aerosols containing chemical insecticides such as, abamectin, fipronil, indoxacarb, imidacloprid, chlorpyriphos, propoxur and chlorfenapyr. Other formulations found in the market include gel, powder, dust, paste and pellets. Structural pests are controlled with oil paints or coating of pesticides at very low concentrations. Few commercial products with low toxic contents have also been promoted by private companies such as, killer bait gel of hydramethylnon (2.15\%) used in sticky traps [2]. Generally, the chemical application in residences can be quite hazardous to human health due to contact toxicity, fumigant action and environmental pollution. Therefore, consumer's preference paradigm is nowadays shifting from toxic chemicals to natural products. Nevertheless, fewer toxic chemicals such as, pyrethrins, silica gel, boric acid and hydramethylnon have been generally recommended for quick effects,

Concerning effectiveness, most of the chemicals do not provide long-term control of certain pests. For example, cockroaches taste food before eating and avoid chemically-treated products. In perspective, alternative measures have therefore been developed and applied with varied degrees of control. Baiting and trapping are successful only on a limited scale because if dust in baits gets wet and then dries and cakes, it loses its electrostatic charge and may not be picked up readily by insects. Pheromone traps can facilitate monitoring the presence and incidence, particularly in hiding sites, of the pest species. Essential oils (EOs) as green pesticides being effective and economically profitable could be used against household and structural pests [3-5]. The common EOs experimented in laboratory are shown in Table 1. As such, it is often advised to restrict to biodegradable, residue-free pesticides that are safe for applicators and residents alike. Currently, published information on chemical-free treatments is limited and not easily available. To fill in this gap, I have compiled literature (2000-2016) and discussed in this review, the use of plant-derived products against important household and structural insect and mite pests with perspective of choice for potential products.

Table 1: Essential Oils Used Against Household and Structural Pests in Laboratory

\begin{tabular}{|c|c|c|c|c|}
\hline $\begin{array}{l}\text { Essential } \\
\text { oil }\end{array}$ & Pest species & $\begin{array}{l}\text { Essential oil } \\
\text { used as }\end{array}$ & $\begin{array}{r}\begin{array}{r}\text { Mode of } \\
\text { action }\end{array} \\
\end{array}$ & Reference \\
\hline Citral & Perplaneta americana & CON, FUM & IN, RE & [6] \\
\hline \multirow{3}{*}{ Eugenol } & P. americana & $\mathrm{CON}$ & IN, RE & [6] \\
\hline & Optotermes formosanus & $s$ CON, FUM & $\mathrm{AF}, \mathrm{IN}$ & [26) \\
\hline & Solenopsis invicta & $\mathrm{CON}$ & $\mathrm{RE}$ & [65] \\
\hline Geranol & P. americana & CON, FUM & $\mathrm{IN}, \mathrm{RE}$ & [6] \\
\hline \multirow[t]{2}{*}{ Limonene } & e $P$. americana & $\mathrm{CON}$ & RE & [7] \\
\hline & C. formosamus & CON, FUM & IN & [41] \\
\hline $\begin{array}{l}\text { Methyl } \\
\text { eugenol }\end{array}$ & $\begin{array}{l}\text { Dermatophagoides } \\
\text { furvus }\end{array}$ & $\mathrm{CON}$ & $\mathrm{AC}$ & [71[ \\
\hline
\end{tabular}

$\mathrm{AC}=$ acaricide, $\mathrm{AF}=$ antifeedant, $\mathrm{CON}=$ contact pesticide, $\mathrm{FUM}=$ fumigant, $\mathrm{IN}=$ insecticidal, $\mathrm{RE}=$ repellent.

\section{Control of insects and mites}

\subsection{Cockroaches (Blattodea)}

\subsubsection{American cockroach}

In control of American cockroach, Periplaneta americana L. (Blattidae), mint/mentha (Mentha spicata L.) oil containing terpenoids, terpenes and phenols (especially, citral, citronellal, gernaniol and eugenol) exerted both repellent and insecticidal activities through fumigant and contact actions when applied to paper at $250 \mathrm{~g}$ oil/g [6]. Citrus (Citrus reticulata Blanco) oil containing limonene repelled adults up to $98 \%$. However, when it was mixed at $10 \%$ with soybean oil, repellency was reduced to $86 \%$ [7]. It means soybean oil can act as antagonist. Both oils were toxic 
to oothecae with $96.7 \%$ egg mortality when mixed with onion (Allium cepa L.) 5\% extract in water [8]. In another experiment, $10 \%$ clove oil exhibited $90 \%$ and $100 \%$ repellency against nymphs and adults, respectively [9]. When used as fumigant at $7.5 \mathrm{ul} / 1,10$ $\mathrm{ul} / 1$ and $8.2 \mathrm{ul} / \mathrm{l}$ of air against first instar nymphs, fourth instar nymphs and adults, respectively, it resulted in $100 \%$ mortality [10]. Clove oil has also been found stronger surface contact toxic with $\mathrm{LC}_{50}$ of $0.0001-0.0077 \mathrm{ul} / \mathrm{cm}^{2}$ than rosemary (Rosmarinus officinalis L.) oil with $\mathrm{LC}_{50}$ of $1.92-2.25 \mathrm{ul} / \mathrm{cm}^{2}$. In this experiment, first instar nymphs were more sensitive than the fourth instar nymphs followed by adults. Consequently, LT $_{50}$ values in continuous exposure test correlated negatively with concentration [11].

A dose of 10,000-80,000 ppm (1-8\%) of essential oil of Piper aduncum L. deterred only nymphs [12] whereas oil of $C$. citratus gave $100 \%$ repellency to adults after $24 \mathrm{~h}$ of application [13] Among three local plants from Thailand (clove, lemon grass and Cymbopogon nardus (L.) Rendle), essential oils extracted from lemon grass in ethyl alcohol and mixed in soybean oil gave $100 \%$ repellency, and this mixture had been recommended as contact poison by Sittichok et al. [9]. Insect growth regulatory (IGR) effects were observed with Azadirachtin (AZ, a limonoid from neem) and two other allelochemicals, e.g. quassin (a triterpenoid from Quassia amara (L.), and cinnamaldehyde (an organic compound from Cinnamomum cassia [Nees \& Nees) Presl.]. These studies demonstrated that physiological effects of these allelochemicals do not ease the primary insecticidal actions [14]. Mode of action of these two products however needs further studies as they can rather act as repellent only. Conclusively, crude oil (lemon grass, citrus or clove) or essential oils when mixed with vegetable oil (sesame or soybean) were more effective than when used alone. To be costeffective, water extract (5\%) should be recommended as it is easy to prepare and apply to structures and places where cockroaches take shelter.

\subsubsection{German cockroach}

Against the German cockroach, Blattella germanica (L.) (Blattelidae), nearly $80 \%$ repellency of acetone extract of catnip (Nepeta concolor Boiss. \& Heldr. ex Benth,) at $900 \mathrm{ug} / \mathrm{cm}^{2}[15]$ or osage orange [Maclura pomifera (Raf.) Schneid] at $157 \mathrm{ug} / \mathrm{cm}^{2}$ [16] was demonstrated. Ethanol and petroleum ether extract of leaves or fruits of the American pepper (Schimus molle L.) when applied topically, adults were not only repelled but later, they were killed [17]. Likewise, crude aqueous extract or acetone extract of pandan leaves initially attracted nymphs but later the repellency was as high as $93 \%$ due to musky odor emitted by aromatic compound 2-acetyl1-pyrroline present in leaves [18].

Sittichok et al. [19] tested EO of eight plants at $0.24 \mathrm{ul} / \mathrm{cm}^{2}$ of filter paper and noted knock-down effect an hour after treatment and complete mortality after $24 \mathrm{~h}$. The most effective oil was extracted from mint (Mentha piperita L.) with $\mathrm{LT}_{50}$ values of $4.17 \mathrm{~h}$. On the contrary, essential oils from Myristica fragrans Houtt. Seeds exerted fumigant action resulting in 35-72\% mortality [20]. Thus, both adults and nymphs were effectively controlled with EO $(1,8$ cineole) which was significantly better in bioefficacy than other 11 essential oils. However, any of the EO tested did not prevent hatching of oothecae. Consequently, multiple applications have been recommended in order to eliminate recurrent infestations [21]. Among hundred plants from family Myrtaceae tested for toxicity, EOs of six species of Eucalyptus and Melaleuca uncinate $\mathrm{Br}$. exhibited strong fumigant action with $100 \%$ mortality in male adults whereas EO of five species of genus Eucalyptus, M. uncinata and Melaleuca dissitiflora Muell., were toxic to both male and female adults. Also, an acetylcholinesterase inhibitory activity with LC50 value of $0.22 \mathrm{mg} / \mathrm{ml}$ was reported with isoeugenol [22]. Likewise, essential oil of Eucalyptus robusta $\mathrm{Sm}$. or Illicium verum Hook. leaves, both applied at $5 \mathrm{ppm}$, and nut grass (Cyperus rotundus L.) at $1 \mathrm{ppm}$ repelled nymphs. On the contrary, essential oils of I. verum and Lindera aggregata (Sims) Kosterm. were found attractive at $1 \mathrm{ppm}$ [23]. Essential oils extracted from osage orange fruit (raw/ripe) acted as repellent because of content of two isoflavones (osajin, pomiferin), seven ses-terpenoids (elemol/hedycaryol, alpha-copaene, alpha-cubebene, beta-elemene, beta-carpophyllene, alpha-ylangene/valencene, (Z, E)-farnesol) and a green volatile compound (hexyl hexanoate) [24]. In a test of five plants [Allium sativum L., Thymus vulgaris (L.), Oregano dubium (L.), onion and rosemary], only EO from A. sativum at $5 \mathrm{ul} / 1$ air caused 95\% mortality within $48 \mathrm{~h}$ [25]. All oils besides their strong repellent action, were toxic and exerted IGR effects resulting in pest mortality.

Contact toxicity of (E)-anethole isolated from $I$. verum fruit was evident to $80 \%$ mortality in adults caused at the dose of 0.159 $\mathrm{mg} / \mathrm{cm}^{2}$ on the first day-after application. It also acted as a fumigant causing $100 \%$ mortality at $0.398 \mathrm{mg} / \mathrm{cm}^{2}$ making this treatment more effective up to $3 \mathrm{~d}$ compared to $2 \mathrm{~d}$ for deltamethrin [26]. A monoterpenoid allyl isothiocyanate isolated from horse-radish (Armoracia rusticana Gaetn., Mey. \& Schreb.) exhibited fumigant action resulting in $100 \%$ mortality at a dose of $2.5 \mathrm{ul} / \mathrm{l}$ of air within $18 \mathrm{~h}$ whereas other monoterpenoids (eugenol, carvacrol, citronella) did not affect pest survival [25]. Unfortunately, these studies were not continued to know the physiological changes that may take place in insect body.

In topical application of 12 essential oils applied at a dose of 0.04 $0.06 \mathrm{mg} / \mathrm{insect}$, thymol was found most toxic to adult males, gravid females and medium nymphs with $\mathrm{LD}_{50}$ values of $0.07,0.12$ and $0.06 \mathrm{mg} /$ cockroach, respectively. On the contrary, transcinnamaldehyde was the most toxic component to adult females, and small and large nymphs. In another dose-dependent assay, (-) menthone had the greatest effect on hatching of oothecae with 20.89 nymphs/ootheca compared to 35.21 nymphs/ootheca in control [27]. In overall performance, not a single essential oil completely prevented hatching. In an assay on nut grass rhizome steam distillate constituents and related compounds against female adults, they were effective in closed but not in open containers. Using video-tracking system, Alzogaray et al. [28] 0bserved that monoterpenes at $70 \mathrm{ug} / \mathrm{cm}^{2}$ produced repellent action but were less effective than N,N-dimethyl-3-methylbenzamide indicating its low bioefficacy. Therefore, essential oils with contact and fumigant activity, particularly, against insecticide-resistant strains, could be recommended to reduce highly toxic synthetic pesticides in indoor environments [29].

As a practical solution, following measures were effective against cockroaches. For example, raw or stewed okra fruits placed under water sink attract cockroaches that can be killed with chemicals. Likewise, bait containing a mixture of citrus pulp + brown sugar + corn meal + boric acid is effective in "attract and kill technique" [30]. Four plants (5\% extract in water) from Nigeria, viz. neem (Azadirachta indica A. Juss.), Parquetina nigrescens (Afzel) Bullock, Zanthoxylum zanthoxyloides (Lam.) and clove, were tested as powder mixed with biscuit at $25-100 \%$. Feeding on biscuits (1.5 g/6 adults) resulted in $85-100 \%$ mortality in $2 \mathrm{~d}$ in $P$. americana adults. [31]. Similarly, Stauffer [30] suggested spraying of rosemary or eucalyptus oil at a conc. of $18 \mathrm{ml} / \mathrm{l}$ or spreading crushed leaves of laurel/sweet bay (Laurus nobilis L.) on floor surface, to repel cockroaches by strong odor. Application of EOs (20\%) derived from kaffir lime, Citrus hystrix DC. exhibited cent per cent repellency against both American and German cockroaches resulting in up to $86 \%$ reduction in pest populations in residences in Thailand [32]. Recently, potassium alum has been used as controlling agent against $P$. americana in the laboratory [33]. Nymphs and adults died (100\% mortality) 4-d and 1-mo respectively, after consuming alum (nymphs $0.3 \mathrm{mg}$, adult male 1 $\mathrm{mg}$, adult female $2.7 \mathrm{mg}$ ). Gravid females are highly susceptible. Alum is cheap and available locally, even in villages, and can be suggested for its use as curative measure.

\subsubsection{Asian cockroach}

Adult populations of the Asian or flying cockroach Blattella asahinai Mizukubo (Blattellidae) were reduced up to $68 \%$ at $7 \mathrm{~d}$ after treatment with essential oil-based emulsifiable concentrate 
(EC) formulation, but control diminished to only $2 \%$ by $30 \mathrm{~d}$ whereas beta cyfluthrin EC or fipronil granules killed cent per cent pest population at $7 \mathrm{~d}$ or $30 \mathrm{~d}$, respectively in the USA [34]. In a comparison of five mulches, there was little preference of $B$. asahinai to cypress (Taxodium distichum (L.) Rich. Therefore, cypress mulch around home may help to reduce pest populations and limit insecticide exposure to humans and animals [35].

\subsubsection{Implications for cockroach management}

Essential oils, plant extracts in water or chemical, and crude oil when used through oral, topical or vapor rotes, were found less effective than synthetic pesticides as contact poison and/or fumigant. Thus, for an alternative to chemicals, a combination of sanitation with traps or granular baits seems to be effective and economic and may be recommended for practical application in residences. All compounds extracted from plants gave reasonable control but in most of the cases, comparative mortality was not studied. Further, plant products, particularly water extracts are easy to prepare, cheap due to round the year-availability of local plant material, and should be recommended in place of two common insecticides (dichlorvos, deltamethrin). Use of alum needs further investigation for side effects. In all treatments, early instar nymphs would be targeted for effective control.

\subsection{Termites (Isoptera)}

\subsubsection{Formosan subterranean termite}

Among chemicals, an IGR hexaflumuron (550-900 mg in bait tubes) [36] or a semisynthetic agent avermectin (3\% dust) (20-30 g in monitor devices) [37] eliminated completely the termites from the infesting sites. When 32 extracts, each at $2000 \mathrm{ppm}(0.2 \%)$ in hexane, ethyl acetate, acetone or methanol of leaves of eight plant species were compared for the control of Formosan subterranean termite (Coptotermes formosanus Shiraki) (Rhinotermitidae), highest mortality of $90 \%$ was achieved $24 \mathrm{~h}$ after treatment with hexane extracts of Aristolchia bracteolate Lam., ethyl acetate extracts of Andrographis paniculata (Burm. f.) Wall. ex Nees, Datura metel L. and Eclipta prostrata (L.) or methanol extract of Andrographis lineata Nees and D. metel [38]. Among leaf extracts and extract derivatives of a Taiwanese plant, Calocedrus macrolepis var. formosana (Florin) Florin, only T-muurolol caused $100 \%$ mortality at $5 \mathrm{mg} / \mathrm{g}$ wood after $14 \mathrm{~d}$ with $\mathrm{LC}_{50}$ value of 27.6 $\mathrm{mg} / \mathrm{g}$ [39].

Blaske and Horst [40] studied repellent action by orientation and avoidance behavior, and toxic effects by contact and fumigation actions of plant extracts. In no-choice test, pest mortality did not occur but termites were effectively prevented from penetrating treated soil. The eucalyptus (Eucalyptus camaldulensis Dehnh.) leaf oil exhibited both contact and fumigant actions with $\mathrm{LC}_{50}$ value of $12.68-17.50 \mathrm{mg} / \mathrm{g}$. Oil extracted from citrus peel (containing $92 \%$ d-liminene) applied at $0.4 \%$ caused $96 \%$ mortality within 5 days [41]. Similarly, catnip oil (containing E-Z-nepetalactone and $\mathrm{Z}$, E-nepetalactone) at $40 \mathrm{mg} / \mathrm{cm}^{2}$ caused $100 \%$ mortality one day after application. At a lower dose of $20 \mathrm{mg} / \mathrm{cm}^{2}$ of E-Znepetalactone, only repellent activity was observed [42]. These examples showed that higher doses of oil are needed for effective pest control.

Essential oils (cedrol, L-cardinol) isolated from heartwood of a Taiwanese plant (Taiwana cryptomerioides Hayata) exhibited a maximum antitermitic activity with $100 \%$ mortality at a dose of 10 $\mathrm{mg} / \mathrm{g}$ wood [43]. Between 100 essential oils, each applied at 10 $\mathrm{mg} / \mathrm{g}$ wood, those extracted from three coniferous plants [e.g. $C . m$. formosana, Cryptomeria japonica (Thunberg) Don, and Chamaecyparis obtusa var. formosana (Hayata], acted as repellent and gave the cent per cent mortality after $5 \mathrm{~d}$ of application. The best treatment was EOs of $C$. m. formosana with $\mathrm{LC}_{50}$ value of 2.6 $\mathrm{mg} / \mathrm{g}$ [44]. From eight essential oils, clove oil at $50 \mathrm{ug} / \mathrm{cm}^{2}$ were most toxic whereas the oil extracted from vetiver, Chrysopogan zizanioides (L.) Roberty acted as repellent only at $5 \mathrm{ug} / \mathrm{g}$ sand, and prevented tunneling at a higher dose of $25 \mathrm{ug} / \mathrm{g}$ sand [45]. Thus, essential oils repelled insects just after application and were toxic in a few days later.

Two phytochemicals (B-cymene and terpinene) derived from eucalyptus leaf oil, showed both contact and fumigant actions whereas 1, 8-cineole acted only as fumigant [46] whereas cinnamaldehyde extracted from Cinnamomum osmophloeum Kaneh. showed comparatively strongest toxicity at $1 \mathrm{mg} / \mathrm{g}$ wood; eugenol and L-terpineol being least effective at the same dose [26]. Boue and Raina [47] studied the effects of oral feeding and topical application on the fecundity, mortality and food consumption in relation to flavonoids of five plants. In these tests, apigenin and biochanin-A fed at 50 ug per reproductive pair proved most toxic. Further, both compounds at 100 ug reduced fecundity and biochanin-A did not elicit phagostimulant activity for adult termites [47]. Mao and Henderson [48] reported antifeedant activity and acute and residual toxicity of alkaloids (matrine and oxymatrine) extracted from Sophora flavescens Ait. With filter paper consumption bioassay, Fokialakis et al. [49] reported that eight thiophenes isolated from five species of genus Echinops gave $100 \%$ mortality within $9 \mathrm{~d}$ when applied at $2 \%$ conc. These findings showed superiority of essential oils over extracts and crude oil.

\subsubsection{Eastern subterranean termite}

Chloroform extracts of dry leaves of Lantana camara L. Applied at $0.016 \mathrm{mg} / \mathrm{cm}^{2}$ of filter paper or $0.125 \mathrm{mg} / \mathrm{g}$ of sand, exhibited excellent repellent, moderate toxic and antifeedant activities against the Eastern subterranean termite, Reticulitermes flavipes (Kollar) (Rhinotermitidae). Higher dose at $0.212 \mathrm{mg} / \mathrm{cm}^{2}$ on filter paper resulted in $>90 \%$ mortality and up to $78 \%$ reduction in feeding whereas topical application (4 ug/termite) resulted in a maximum of $60 \%$ mortality. Thus, filter paper treatment showed superiority over other methods [50]. More trials may be necessary for practical application in houses. The eastern red cedar (Juniperus virginiana L.) oil extracted from heart wood, and ethanol extracts of needles proved lethal and prevented termites from damaging wood [51]. Heartwood was more resistant than sapwood due to presence of essential oils and other allelochemicals. Therefore, there was less pest infestation $((2.1-6.1 \%$ versus $44.6 \%)$ and termite survival $(<24 \%$ versus $>84 \%)$ in cedar wood than in susceptible pine wood [52].

\subsubsection{Building termite}

Leaf extracts (5\%) of L. camara in chloroform gave up to $68 \%$ mortality $48 \mathrm{~h}$ after application of the building termite, Microcerotermes beesoni Snyder (Termitidae), and extract of Ageratum conyzoides L. leaves in petroleum ether or hexane showed 67\% repellency [53]. Further, Kaur and Rawat [54] evaluated extracts in water or chemicals of leaves of six plants, seeds of two plants and root of one plant and finally. They recommended the leaf extracts $(0.1 \%)$ in petroleum ether of $\mathrm{L}$. camera; ethanol extracts $(0.1 \%)$ of Murraya keonigii (L.) Spreng. Or methanol extract $(0.1 \%)$ of cassia, Senna (Cassia) occidentalis (L.) Link. These treatments caused $100 \%$ pest mortality within 24 $\mathrm{h}$ of application. Similarly, essential oil extracted from $M$. fragrans gave $100 \%$ mortality $14 \mathrm{~d}$ after treatment at a dose of $5 \mathrm{mg} / \mathrm{g}$ wood with $\mathrm{LC}_{50}$ of $28.6 \mathrm{mg} / \mathrm{g}$ [55]. Extract in water is comparatively cheaper than chemicals and easy to prepare with readily available local materials. For example, L. camara is a weed abundantly found in village surroundings, fallow lands, field bunds and roadside, its extract may therefore be suggested.

In India, Lakshmanan [56] found potential in controlling building termite by spraying water extract $(>10 \%)$ of Euphorbia clavarioides Boiss. var. truncata (N.E.Br.) White, Dyer \& Sloane, Aloe lateritia var. germinicola (Reynolds), Melia azedarach L., Lippia javanica (Burm. f.) Spreng or Ocimum sanctum L., and neem oil (NO) mixed in kerosene. Moreover, $20 \%$ crude oil of jatropha (Jatropha curcas L.) reduced greater weight loss in treated wood (18.8-48.8\% compared to oil fractions with 10.5-35.2\% loss) or untreated wood (50.8\% loss) [57]. 


\subsubsection{Asian subterranean termite}

Defatted NO at $7.5 \%$ was better than AZ (91\% purity) as antifeedant, oviposition deterrent, IGR or contact poison against the Asian subterranean termite, Coptotermes gestroi Wasmann (Rhinotermitidae) [58]. Bark powder extracts in ethyl acetate of Rhizophora apiculata Blume showed toxic activity due to presence of aromatic carboxylic acids and phenols [59].

\subsubsection{Egyptian subterranean termite}

In the Middle East, the Egyptian subterranean termite, Anacanthotermes ochraceus (Burm.) (Hodotermitidae) was managed by spraying wooden structures with an aqueous extract of four Saharan toxic plants but only (Willd.) Ait. extract in water resulted in a significantly higher pest mortality (maximum of 50\%) than with other plants (Hyoscyamus muticus L., Pergularia tomentosa and Datura stramonium L.) [60]. Comparatively, imported wood was resistant to pest attack. Therefore, isolation and characterization of allelochemicals and their use as repellent or antifeedant may lead to improvement in current pest control [61].

\subsubsection{Implications for termite management}

Subterranean termites are a problem in developing, and lessdeveloped countries where houses are constructed with local material (bamboo, plant stalks, crop residue). Considering easy availability of commercial products in the market, crude oil of neem, jatropha, eucalyptus and jatropha can be a suitable remedy For example, water extracts (especially of neem and lantana), crude oil and essential oils were found effective against majority of termite species in India [62]. Most of these products showed various modes of action such as, antifeedant, repellent, IGR and toxic. New plant-derived products include coconut shell oil. Its coating reduced termite infestation from $100 \%$ in untreated wood to $34.2 \%$ in treated wood, and protected wood up to 18 mon [63]. Furthermore, pine (Pinus sp.) resin derivatives (diterpene acids) helped to reduce termite damage [64]. Thus, coconut shell oil and resin can be effectively used as protectant (preventive coating) against termites. After evaluating marketed formulations and crude preparations, preference should be given to products based on the indigenous plant species which are readily available in plenty.

\subsection{Ants (Hymenoptera)}

Not much research has been undertaken on ant control since they are easily managed by boric acid, silica aerogel, aerosol sprays, and diatomaceous dusts or NO sprays. In the digging bioassay, Chen [65] observed that a commercial product containing essential oil when applied to send at $100 \mathrm{mg} / \mathrm{kg}$, it was repellent to adults of the red imported fire ant, Solenopsis invicta Buren (Formicidae) Among compounds tested by Chen [65], eugenol, menthol and methyl salicylate were significantly more effective than camphor and eucalyptol (all applied at $10 \mathrm{mg} / \mathrm{kg}$ of sand). These essential oils may be further studied for sand application to prevent ant entry into house premises and can be considered as preventive measure.

\subsection{Silverfish (Thysanura)}

In the laboratory, essential oils of Cryptomeria japonica D. Don leaves (containing elenol, 16-kaurene, 3-carene and other compounds) exhibited $80 \%$ repellency to common silverfish or fish moth, Lepisma saccharina Linn. (Lepismidae), at a dose of 0.01 $\mathrm{mg} / \mathrm{cm}^{2}$ and $100 \%$ mortality at $0.16 \mathrm{mg} / \mathrm{cm}^{2}$ within $10 \mathrm{~h}$ of application [66]. In residences, essential oils (myrtenol, myrtenal, alpha-pinene) extracted from the Formosan cypress plant, Chamaecyparis formosensis Matsum sprayed in the air at 0.16 $\mathrm{mg} / \mathrm{cm}^{3}$ space completely killed the pest within $8 \mathrm{~h}$ of application [67]. Sprays of EO on surface or in air would be appropriate for effective pest control.

\subsection{Psocids (Psocoptera)}

Essential oil of Cupressus funebris Endl. or Eucalyptus citriodora at low dose of $10 \mathrm{ppm}$ showed repellent effect to common psocid or book lice, Liposcelis bostrychophila Badonnet (Liposcelidae) and was toxic when used at high dose of $20 \mathrm{ppm}$ for fumigation. Action was enhanced significantly when EO were combined with $12 \% \mathrm{CO}_{2}+9 \% \mathrm{O}_{2}$ or balanced $\mathrm{N}_{2}$ [68]. Between 28 compounds of essential oil extracted from Kaempferia galanga., only transcinnamaldehyde exerted contact, fumigant and repellent actions [69]. Extraction of essential oils is costly, crude oils may therefore be tested at least for repellency.

Wheat germ and wheat germ oil attract psocids which could be killed with chemical pesticides [70]. This is a practical solution to pest infestation problem in residences and can be recommended while taking proper precautions for pesticide application.

\subsection{House dust mites (Acarina)}

Acaricidal activity of oil extracted from the clove buds [71], neem or lemon grass [72] has been reported. According to Kim et al. [71], the most effective constituent for contact toxicity is methyl eugenol at a dose of $0.94 \mathrm{ug} / \mathrm{cm}^{2}$ and $0.67 \mathrm{ug} / \mathrm{cm}^{2}$ against the European house dust mite Dermatophagoides farina Huges (Pyroglyphidae) and the American house dust mite, Dermatophagoides pteronyssinus (Trouessart) (Pyroglyphidae), respectively. Application of eugenol, acetyl eugenol, isoeugenol or methyl eugenol was effective as fumigant against both mite species and resulted in higher pest mortality than chemical DEET at 17.85 $\mathrm{ug} / \mathrm{cm}^{2}$ [71]. Traditionally, eucalyptus oil is used to prevent pest infestation. More research is needed to verify bioefficacy of allelochemicals.

\section{Looking ahead}

!1) Salehzadelia and Mahjub [73] reported antagonistic effect of AZ mixed with pyrethroids $(0.5 \%$ cyfluthrin $10 \mathrm{WP}$ or $0.1 \%$ permethrin 25WP) against German cockroach. This is possible since these products belong to different groups of pesticides with different modes of action. Further, antagonistic effect might be due to competition for same site or some conformational changes in target sites or receptors. Extensive studies are therefore needed to confirm these findings to include in pest management strategy. Research on structure activity relationship would reveal why some essential oils are toxic and other are not toxic. Similarly, laboratory findings are to be put in practice for effective pest control by undertaking extension activity.

(2) Regulation to harmonize the overall arrangement for authorization of plant products differs in each country and the legislation for execution of rules is under different ministries. Generally, the list of active substances is regularly published by the competent authority. Also, bulletins and gazettes are available with international organizations [74]. In fewer developed and developing countries, standardizations for the content of active ingredients in crude extracts or commercial products are not often followed probably because laboratory facilities are inadequate or non-existing, and procedure is expensive [75]. This aspect is important as the content varies considerably as per ago-climatic zones, collection and processing of raw material and methods of extraction [76]. For marketing, similar official procedure is imposed for registration and for granting license for synthetic pesticides and plant products. Plant products are labelled with green sign or category IV of the pesticides. Therefore, information provided in this paper is essentially scientific or technical in nature and cannot be used without complying current regulations and respecting procedure for any treatment in houses.

(3) Operators sometimes mix locally available products as synergists or adjuvants (particularly kerosene, medicinal herbs) in spray tank and apply against pests and unregistered plant products are used illegally and their use results in partial pest control [75]. Not wearing of protective clothing is another reason for chronic exposure to plant products. Information on category of toxicity, expiry date, antidotes in case of accidental poisoning etc. is clearly 
given on the container label and product leaflet [77]. Whenever sprays containing essential oils are used, inhalation can be problematic for human health. Precautions should therefore be advocated during such applications in houses or surroundings. Otherwise, accidental poisoning occurs particularly when operators are not well trained or not fully aware of operations to be carried out. For example, ingestion of unrefined NO [78], purified terpenoid constituents of essential oil [3] or AZ [79] can cause moderate poisoning or mammalian toxicity. Human and animal studies showed that unprocessed material (seed oil, aqueous extracts) are less toxic than non-aqueous extracts and can be applied inside residences with proper care [80]. Essential oils gave promising results but ready-to-use formulations are needed to make them easily available to applicators.

(4) Since NO is commonly used in medical and cosmetic products, it is stored inside houses where hand to mouth exposure can pose health problems. In fact, NO is likely to be carcinogenic and causes toxic encephalopathy [81]. On the contrary, cold-pressed neem oil (CPNO) is comparatively safe to humans, predators and parasitoids of insects, honey bees and other pollinators except it is slightly toxic to aquatic organisms in laboratory, and honey bees have been reported to avoid food that contains $>100 \mathrm{ppm}$ of CPNO [82], and its "indoor use" have been approved by EPA in the USA [82]; it can therefore be recommended in other countries against household and structural pests.

\section{Acknowledgment}

I am greatly thankful to my colleagues for reviewing the manuscript and suggesting certain modifications on toxicity data.

\section{References}

[1] W.H. Robinson, Urban insects and arachnids: A handbook of urban entomology. Cambridge University Press London, UK, 2005. https://doi.org/10.1017/CBO9780511542718.

[2] C. Wang, G.W. Bennett, Comparative study of integrated pest management and baiting for German cockroach management in public housing. Journal of Economic Entomology 99 (2006) 879. 885. https://doi.org/10.1093/jee/99.3.879.

[3] M.B. Isman, Plant essential oils for pest and disease management Crop Protection 19 (2000) 603-608. https://doi.org/10.1016/S02612194(00)00079-X.

[4] O. Koul, S. Walia, G.S. Dhaliwal, Essential oils as green pesticides: Potential and constraints. Biopesticides Internatonal 4 (2008) 63-84

[5] C. Regnault-Roger, C. Vincent, J.T. Arnason, Essential oils in insect control: low-risk products in a high-stakes world. Annual Review of Entomology 57 (2012) 405-424. https://doi.org/10.1146/annurevento-120710-100554.

[6] A.G. Appel, M.J. Gehret, M.J. Tanley, Repellency and toxicity of mint oil to American and German cockroaches (Dictyoptera: Blattidae and Blattellidae). Journal of Agriculture and Urban Entomology 18 (2001) 149-156.

[7] C. Yoon, S.H. Kang, J.O. Yang, D.J. Noh, I. Pandiyan, G.H. Kim, Repellent activity of citrus oils against cockroaches, Blattella germanica, Periplaneta americana and P. fuliginosa. Journal of $\begin{array}{llll}\text { Pesticide } & \text { Science } & \text { 34(2) } & \text { (2009) }\end{array}$ https://doi.org/10.1584/jpestics.G07-30.

[8] K.S. Sittichok, M. Soowera, Repellent activity and oothecal toxicity of eight herbal essential oils against American cockroach, Periplaneta americana L., Blattidae: Blattodea). Proceedings of the

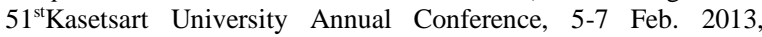
Bangkok, Thailand, 2013.

[9] K.S. Sittichok, W. Phaysa, M. Soowera, Repellency activity of essential oil of Thai local plants against American cockroach (Periplaneta americana L., Blattidae: Blattodea). Journal of Agricultural Technology 9 (2013) 1613-1626.

[10] S.M. Omara, K.M. Al-Ghamdi, M.A.M. Mahmood, S.E. Sharawi, Repellency and fumigant toxicity of clove and sesame oils against American cockroach, Periplaneta americana (L.). African Journal of Biotechnology 12 (2013) 963-970.

[11] S.E. Sharawi, S.M. Abd-Alla, S.M. Omara, K.M. Al-Ghamdi, Surface contact toxicity of clove and rosemary oils against American cockroach, Periplaneta americana (L.). African Entomology 21(2013) 324-332. https://doi.org/10.4001/003.021.0204.

[12] A.L.Ling, Sulaiman, H. Othman, Evaluation of Piper aduncum Linn essential oil (Family: Piperaceae) against Periplaneta americana (L.) Iranian Journal of Arthropod- borne Diseases 3(2) (2009) 1-6.

[13] F. Manzoor, N. Munir, A. Amdreen, S. Naz, Efficacy of some essential oils against American cockroach, Periplaneta americana(L.). Journal of Medicinal Plants Research 6 (2012) 1065 1069.

[14] W. Hertel, P.J. Muller, Physiological effects of the natural products quassin, cinnamaldehyde and azadirachtin on Periplaneta americana (L.). Journal of Applied Entomology 130 (2006) 323-328 https://doi.org/10.1111/j.1439-0418.2006.01065.x.

[15] C.I. Peterson, L.T. Nemetz, L.M. Jones, J.R. Coats, Behavioral activity of catnip (Lamiaceae) essential oil components to the German cockroach (Blattodea: Blattellidae). Journal of Economic Entomology 95 (2010) 377-380. https://doi.org/10.1603/0022-049395.2.377.

[16] G. Schultz, C. Peterson, J. Coats, Natural insect repellents: activity against mosquitoes and cockroaches. Natural products for pest management ACS symposium series no. 927, American Chemical Society, Washington, DC, USA, 2006, 168-180.

[17] A.A. Ferrero, C.S. Chopa, J.O.W. Gonzalez, R.A. Alzogaray, Repellence and toxicity of Schimus molle extracts on Blattellagermanica.Fitoterapia7 (2007) 311-314.

[18] J. Li, S.H. Ho, Pandan leaves (Pandanus amaryllifolius Roxb.) as a natural cockroach repellent. Proceedings of $9^{\text {th }}$ Natural undergraduate research opportunities program, National University of Singapore, Singapore, 2003.

[19] K.S. Sittichok, M. Soowera, R. Dandong, Toxicity activity of herbal essential oils against German cockroach (Blattella germanica L., Blattellidae). Journal of Agricultural Technology 9 (2013) 16071612.

[20] W.C. Jung, Y.S. Jang, T.T. Hieu, C.K. Lee, Y.J. Ahn, Toxicity of Myristica fragrans seed compounds against Blattella germanica (Dictyoptera: Blattellidae). Journal of Medical Entomology 44 (2007) 524-529. https://doi.org/10.1093/jmedent/44.3.524.

[21] A.K. Phillips, A.H. Appel, Fumigant activity of essential oils to the German cockroach (Dictyoptera: Blattellidae). Journal of Economic Entomology 103 (2010) 781-790. https://doi.org/10.1603/EC09358.

[22] H.J. Yeom, J. Kang, S.W. Kim, I.K. Park, Fumigant and contact toxicity of Myrtaceae plant essential oils and blends for their constituents against adults of German cockroach (Blattella germanica) and their acetylcholinesterase inhibitory activity. Pesticide Biochemistry and Physiology 107 (2013) 200-206. https://doi.org/10.1016/j.pestbp.2013.07.003.

[23] Z.L. Liu, M. Yu, X.M. Li, T. Wan T, S.S. Chu, Repellent activity of eight essential oils of Chinese medicinal herbs to Blattella germanica L. Records of Natural Products5 (2011) 176-183.

[24] C.I. Peterson, J. Zhu, J.R. Coats, Identification of components of osage orange fruit (Maclura pomifera) and their repellency to German cockroaches. Journal of Essentials Oil Research 14 (2002) 233-236. https://doi.org/10.1080/10412905.2002.9699833.

[25] H. Tunaz, M.K. Er, A.A. Isikber, Fumigant toxicity of plant essential oils and selected monoterpenoid components against the adult German cockroach, Blattella germanica (L.) (Dictyoptera: Blattellidae). Turkish Journal of Agriculture and Forestry 33 (2009) 211-217.

[26] S.T. Chang, S.S. Cheng, Antitermitic activity of leaf essential oils and their constituents from Cinnamomum osmophloem. Journal of Agricultural and Food Chemistry 50 (2002) 1389-1392. https://doi.org/10.1021/jf010944n.

[27] A.K. Phillips, A.H. Appel, S.R. Sims, Topical toxicity of essential oils to the German cockroach (Dictyoptera: Blattellidae). Journal of

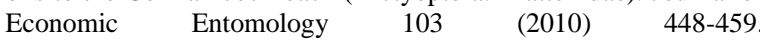
https://doi.org/10.1603/EC09192.

[28] R.A. AlzogarayA. Lucia, E.N. Zerba,.H.M. Masuh, Insecticidal activity of essential oils from eleven Eucalyptus spp. and two hybrids: Lethal and sublethal effects of their major components on Blattella germanica .Journal of Economic Entomology 104 (2011) 595- 600.

[29] K.S. Chang, E.H. Shin, C. Park, Y.J. Ahn, Contact and fumigant toxicity of Cyperus rotundus steam distillate constituents and related compounds to insecticide-susceptible and resistant Blattella germanica. Journal of Medical Entomology 4 (2012) 631-639. https://doi.org/10.1603/ME11060.

[30] R. Stauffer, Cockroaches, The environmentally friendly pest control, series no. 1, University of Nevada Cooperative Extension, Las Vegas, Nevada, USA, 2009. 
[31] R.F. Ogunleye, Toxicity bioassays of products from different botanicals against the household pest, Periplaneta americana (Linnaeus). Journal of Science and Technology 30(2) (2010) 29-35.

[32] U. Thavara, A. Tawatsin, P. Bhakdeenuan, P., Repellent activity of essential oils against cockroaches (Dictyoptera: Blattidae, Blattellidae and Blaberidae) in Thailand. Southeast Asian Journal of Tropical Medicine and Public Health 38 (2007) 663-673.

[33] E.M. Salama, A novel use for potassium alum as controlling agent against Periplaneta americana (Dictyoptera: Blattidae). Journal of $\begin{array}{llll}\text { Economic } & \text { Entomology108 (2015) } & 2620- & \end{array}$ https://doi.org/10.1093/jee/tov239.

[34] E.T. Snoddy, A.G. Appel, Field and laboratory efficacy of three insecticides for population management of the Asian cockroach (Dictyoptera: Blattellidae). Journal of Economic Entomology $l 107$ (2014) 326-332. https://doi.org/10.1603/EC13342.

[35] E.T. Snoddy, A.G. Appel, Mulch preferences of the Asian cockroach (Dictyoptera: Blattellidae). Journal of Economic Entomology $l 106$ (2013) 322-326. https://doi.org/10.1603/EC12032.

[36] M.T. Messenger, N.Y. Su, C. Jusseneder, J.K. Grace, Elimination and reinvasion studies with Coptotermes formosanus (Isoptera: Rhinotermitidae) in Louisiana. Journal of Economic Entomology 98 (2005) 916-929. https://doi.org/10.1603/0022-0493-98.3.916.

[37] J. Zhao, Y. Dong, B. Yu, Z. Zhang, J. Mo, Ivermectin dust for the control of Coptotermes formosanus in residential areas. Sociobiology 59 (2012) 1365-1373.

[38] G. Elango, A. Abdul Rahman, C. Kamaraj, A. Bhagavan, A. AbduzZahir, T. Santhoshkumar, S. Marimuthu, K. Velayutham, C. Jayaseelan, H.V. Kirthi, G. Rajakumar, Efficacy of medicinal plant extracts against Formosan subterranean termite, Coptotermes formosanus. Industrial Crops and Products 36 (2012) 524-530. https://doi.org/10.1016/j.indcrop.2011.10.032.

[39] S.S. Cheng, C.L. Wu, H.T. Chang, Y.T. Kao, S.T. Chang, Antitermitic and antifungal activities of essential oil of Calocendrus formosana leaf and its composition. Journal of Chemical Ecology 30 (2004) https://doi.org/10.1023/B:JOEC.0000045588.67710.74.

[40] V.U. Blaske, H. Horst, Repellent and toxic effects of plant extracts on subterranean termites (Isoptera: Rhinotermitidae). Journal of $\begin{array}{lllll}\text { Economic } & \text { Entomology } 94 \quad \text { (2001) } 1200- & \end{array}$ https://doi.org/10.1603/0022-0493-94.5.1200.

[41] A. Raina, J. Bland, M. Doolittle, A. Lax, R. Boopathy, M. Folkins, Effect of orange oil extract on the Formosan subterranean termite (Isoptera: Rhinotermitidae). Journal of Economic Entomology100 (2007) 880-885. https://doi.org/10.1093/jee/100.3.880.

[42] K.R. Chauhan, A.K. Raina, Effect of catnip oil and its major compounds on the Formosan subterranean termite (Coptotermes formosanus). Biopesticides International 2 (2006) 137-143.

[43] S.T. Chang, S.S. Cheng, S.Y. Wang, Antitermitic activity of essential oils and components from Taiwan (Taiwania cryptomerioides).Journal of Chemical Ecology 27 (2001)717-724. https://doi.org/10.1023/A:1010397801826.

[44] S.S. Cheng, H.T. Chang, C.L. Wu, S.T. Chang, Anti-termitic activities of essential oils from coniferous trees against Coptotermes formosanus. Bioresource Technology 98 (2007) 456-459. https://doi.org/10.1016/j.biortech.2006.01.006.

[45] B.C.R. Zhu, G. Henderson, F. Chen, H.X. Fei, R. Laine, Evaluation of vetiver oil and seven insect-active essential oils against the Formosan subterranean termite. Journal of Chemical Ecology 27 (2001) 1617-1625. https://doi.org/10.1023/A:1010410325174

[46] P. Siramon, Y. Ohtani, H. Ichiura, Biological performance of Eucalyptus camaldulensis leaf oils from Thailand against the subterranean termite, Coptotermes formosanus Shiraki. Journal of Wood Science 55 (2009) 41-46. https://doi.org/10.1007/s10086-0080990-4.

[47] S.M. Boue, A.K. Raina, Effects of plant flavonoids on fecundity, survival and feeding of the Formosan subterranean termite. Journal of Chemical Ecology $29 \quad$ (2003) 2575-2584. https://doi.org/10.1023/A:1026318203775.

[48] L. Mao, G. Henderson, Antifeedant activity and acute and residual toxicity of alkaloids from Sophora flavescens (Leguminosae) against Formosan subterranean termites (Isoptera: Rhinotermitiade). Journal of Economic Entomology100 (2007) 866-870. https://doi.org/10.1093/jee/100.3.866.

[49] N. Fokialakis, W.I.A. Osbrink, I.K. Mamonov, N.G. et al., Cantrell, Antifeedant and toxicity effects of thiopenes from four Echinops species against the Formosan subterranean termite, Coptotermes formosanus. Pest Management Science 62 (2006) 832-838. https://doi.org/10.1002/ps.1237.

[50] Z. Yuan, X.P. Hu, Repellent, antifeedant and toxic activities of Lantana camara leaf extract against Reticulitermes flavipes
(Isoptera: Rhinotermitidae).Journal of Economic Entomology 105 (2012) 2115-2121. https://doi.org/10.1603/EC12026.

[51] F.J. Eller, C.A. Clausen, F. Green, S.L. Taylor, Critical fruit extraction of Juniperus virginiana L. and bioactivity of extracts against subterranean termites and wood-rot fungi. Industrial Crops and Products $32 \quad$ (2010) 481-485. https://doi.org/10.1016/j.indcrop.2010.06.018.

[52] B. Kard, S. Hiziroglu, M.E. Payton, Resistance of eastern red cedar panels to damage by subterranean termites (Isoptera: Rhinotermitidae). Forest Products Journal 57(11) (2007) 74-79.

[53] S.K. Verma, R.K. Verma, K.D. Saxena, Bioefficacy of herbal extracts against building termite, Microcerotermes beesoni. Pestology 28(6) (2004) 19-22.

[54] M. Kaur, B.S. Rawat, Antitermitic properties of selected plant extractives against building infesting termite, Microcerotermes beesoni Snyder. Pestology37(8) (2013) 11- 14.

[55] M. Pal, R. Kumar, S.K. Tewari, Antitermite activity of essential oil and its components from Myristica fragrans against Microcerotermes beesoni. Journal of Applied Sciences and Environmental Management15 (2002a) 597-599.

[56] K.K. Lakshmanan, Indigenous methods of integrated termite management. Indian Farmers' Digest 35(1) (2002) 25-27.

[57] N. Singh, A. Sushilkumar, Anti-termite activity of Jatropha curcas Linn, biochemicals. Journal of Applied Sciences and Environmental Management 12(3) (2008) 67-69.

[58] S.K. Himmi, D. Tarmadi, M. Ismayati, S. Yusuf, Bioefficacy performance of neem- based formulation on wood protection and soil barrier against subterranean termite, Coptotermes gestroi Wasmann (Isoptera: Rhinotermitidae). Proceedings of Environmental Science 17 (2013) 135-141. https://doi.org/10.1016/j.proenv.2013.02.021.

[59] H.P.S.A. Khalil, N.H. Kong, M.N. Ahmad, A.H. Bhat, M. Jawaid, S. Jumat, Selective solvent extraction of the bark of Rhizophora apiculata as an anti-termite agent against Coptotermes gestroi Journal of Wood Chemistry and Technology 29 (2009) 286-304 https://doi.org/10.1080/02773810903165663.

[60] Y. Bourmita, A. Cheriti, M.D. Ould El-hadi, K. Mahmoudi, N. Belboukhari, Anti- termitic activity of aqueous extracts from Saharan toxic plants against Anacanthotermes ochraceus. Journal of $\begin{array}{llll}\text { Entomology } & 10 & \text { (2013) 207-213. }\end{array}$ https://doi.org/10.3923/je.2013.207.213.

[61] W. Kaakeh, Survival and feeding responses of Anacanthatermes ochraceus (Hodotermitidae: Isoptera) to local and imported wood. Journal of Economic Entomology 98 (2005) 2137-2142. https://doi.org/10.1093/jee/98.6.2137.

[62] M. Verma, S. Sharma, R. Prasad, Biological alternatives for termite control: A review. International Biodeterioration \& Biodegradation 63 (2009) 959-972. https://doi.org/10.1016/j.ibiod.2009.05.009.

[63] K.S. Shiny, O.K. Remadevi, Evaluation of termicidal activity of coconut shell oil and its comparison to commercial wood preservatives. European Journal of Wood and Wood- Products 72 (2014) 139-141. https://doi.org/10.1007/s00107-013-0755-7.

[64] I. Nunes, T. Nobre, B. Gigante, A.M. Silva, Toxicity of pine resin derivatives in subterranean termites (Isoptera: Rhinotermitidae). Management of Environmental Quality 15 (2004) 521-528. https://doi.org/10.1108/14777830410553960.

[65] J. Chen, Repellency of an over-the-counter essential oil product in China against workers of red imported fire ants. Journal of Agricultural and Food Chemistry 57 (2009) 618-622. https://doi.org/10.1021/jf8028072.

[66] S.Y. Wang, W.C. Li, F.H. Chu, C.T. Lin, S.Y. Shen, S.T. Chang, Essential oil from the leaves of Cryptomeria japonica acts as a silverfish (Lepisma saccharina) repellent and insecticide. Journal of Wood Science 52 (2006) 522-526. https://doi.org/10.1007/s10086006-0806-3.

[67] P.M. Kuo F.H. Chu, S.T. Chang, W.F. Hsiao, S.Y. Wang, Insecticidal activity of essential oil from Chamaecyparis formosensis $\begin{array}{llll}\text { Matsum. } & \text { Holzforsch } & 61 & \text { (2007) }\end{array}$ https://doi.org/10.1515/HF.2007.087.

[68] J.J. Wang, H. Tasi, W. Ding, Z.M. Zhao, L.S. Li, Toxic effects of six plant oils alone and in combination with controlled atmosphere on Liposcelis bostrychophila (Psocoptera: Liposcellididae). Journal of $\begin{array}{llllll}\text { Economic } & \text { Entomology } & l & 94 & \text { (2001) } & 1296-1301 .\end{array}$ https://doi.org/10.1603/0022-0493-94.5.1296.

[69] L. Liu, Y. Liang, W.P. Shi, Q.Z. Liu, I. Zhou, Z.I. Liu, Repellent and insecticidal effects of the essential oil of Kaempferia galanga rhizomes to Liposcelis bostrychophila (Psocoptera: Liposcelidae) Journal of Economic Entomology107 (2014) 1706-1712. https://doi.org/10.1603/EC13491.

[70] J. Diaz-Montano, J.F. Campbell, T.W. Philips, Throne JE Evaluation of potential attractants for Liposcelis bostrychophila (Psocoptera: 
Liposcelididae). Journal of Economic Entomology 107 (2014) 867874. https://doi.org/10.1603/EC13427.

[71] E.H. Kim, H.K. Kim, Y.J. Ahn, Acaricidal activity of clove bud oil against Dermatophagoides farina and Dermatophagoides pteronyssinus (Acari: Pyroglyphidae). Journal of Agricultural and $\begin{array}{lllll}\text { Food } & \text { Chemistry } & 51 & \text { (2003) } & \text { 885-889. }\end{array}$ https://doi.org/10.1021/jf0208278.

[72] A.L. Hanifah, S.H. Awang, H.T. Ming, S.Z. Abidin, M.H. Omar, Acaricidal activity of Cymbopogan citratus and Azadirachta indica against house dust mites. Asian Pacific Journal of Biomedicine 1 (2011) 365-369. https://doi.org/10.1016/S2221-1691(11)60081-6.

[73] A. Salehzadeha, H. Mahjub, Antagonistic effect of azadirachtin on cyfluthrin and permethrin. Journal of Entomology 8 (2011) 95-100. https://doi.org/10.3923/je.2011.95.100.

[74] FAO, Azadirachtin: FAO specifications and evaluations for agricultural pesticides. Plant Production and Protection Division, FAO, Rome, Italy, 2003. http://www.fao.org/ag/agpp/pesticid/.

[75] R.T. Gahukar, Potential and utilization of plant products in pest control. Integrated pest management: current concepts and ecological perspective. Elsevier Inc., New York, NY, USA, 2014, 125-139. https://doi.org/10.1016/b978-0-12-398529-3.00009-9.

[76] R.T. Gahukar, Factors affecting content and bioefficacy of neem (Azadirachta indica A. Juss.) phytochemicals used in agricultural pest control: a review. Crop Protection 62 (2014) 93- 99. https://doi.org/10.1016/j.cropro.2014.04.014.

[77] J.T. Trumble, Caveat emptor: safety considerations for natural products used in arthropod control. American Entomologist 48 (2002) 7-13. https://doi.org/10.1093/ae/48.1.7.

[78] R.K. Dhongade, S.G. Kawade, R.S. Damle, Neem oil poisoning. Indian Pediatrics 45 (2008) 56-58.

[79] R. Iyyadurai, V. Surekha, S. Sathendra, B.P. Wilson, K.G. Gopinath, Azadirachtin poisoning: a case report. Clinical Toxicology 48 (2010) 857-858. https://doi.org/10.3109/15563650.2010.518148.

[80] S.J. Boeke, M.G. Boersma, G.M. Alink, J.J.A. et al., Safety evaluation of neem (Azadirachta indica) derived pesticides. Journal $\begin{array}{llll}\text { of } & \text { Ethnopharmacology } & 94 & \text { (2004) }\end{array}$ https://doi.org/10.1016/j.jep.2004.05.011.

[81] A. Mishra, N. Dave, Neem oil poisoning: case report of an adult with toxic encephalopathy. Indian Journal of Critical Care Medicine 17(5) (2013) 321-322.

[82] EPA, Biopesticides registration section document, Biopesticides and Pollution Prevention Division, Environmental Prevention Agency, USA, 21 pp., 2012. 